\section{B A Institute of \\ YK Business Administration \\ 六下 \\ Karachi \\ Leadership and Ideas for Tomorrow}

Business Review

Volume 1 Issue 1 July - December 2006

7-1-2006

\title{
Mechanisms underlying the phenomenon of cluster formation in the textile/apparel industry in Pakistan
}

Khadija Bari

Institute of Business Administration, Karachi, Pakistan

Follow this and additional works at: https://ir.iba.edu.pk/businessreview

Part of the Business Commons

\section{(c) (1)}

This work is licensed under a Creative Commons Attribution 4.0 International License.

\section{Recommended Citation}

Bari, K. (2006). Mechanisms underlying the phenomenon of cluster formation in the textile/apparel industry in Pakistan. Business Review, 1(1), 106-124. Retrieved from https://doi.org/10.54784/ 1990-6587.1098 


\title{
ARTICLE \\ Mechanisms Underlying the Phenomenon of Cluster Formation in the Textile/Apparel Industry in Pakistan
}

\begin{abstract}
The objective of this study is to analyze the ability of Pakistan's textile industry to broaden and upgrade its competitive positions in the face of increasing international competition. It suggests a conceptual framework of organisational characteristics influencing the process and formation of clusters. Clusters are a driving force in increasing exports and magnets for attracting foreign investment. The cluster concept represents a new way of thinking about national, state, and city economies, and points to new roles for companies, governments, and other institutions striving to enhance competitiveness.

The paper is based on empirical analysis of the organizational characteristics and intra-cluster interchange in the textile/apparel industry of Pakistan. It represents the results obtained from the information collected from 39 establishments by a structured questionnaire. It examines the institutional context with which the firms of the textile/apparel industry in Pakistan operate and analyses the local linkage pattern and cluster formation process of this industry in Pakistan. Some policy implications for the growth and sustained competitiveness of this industry in Pakistan are considered and discussed in this paper.
\end{abstract}

Khadija Bari

Keywords: Clusters, Competitive Advantage, Industrial Linkages

\section{INTRODUCTION AND BACKGROUND}

The textile industry holds a prominent position in many Asian countries. It is an 1 industry well suited to the early stage of industrialization as it requires neither a high level of technology nor a large amount of capital. Its labour intensive nature makes it a popular industry in the less industrialized countries which can make the most of their low wages.

Now global textile industry is passing through an interim phase of structural changes. Those changes are the consequence of expected changing in the global trade patterns under the open competition policy. What will be the expected share in global markets and how present ranking will be affected by the trade liberalization; it is an extremely important area that needs timely consideration.

Asian countries dominate the apparel markets of the world. Almost $45 \%$ of the total exports in the apparel markets originate from the Asian countries which include key 
players like China, Hong Kong, Thailand, Turkey, Bangladesh, India and Pakistan. China's particularly unlimited supply of cheap labor gives it a big advantage in the labor intensive industry like clothing. China further more is almost self-sufficient in the necessary raw material - cotton, manmade fibers, silk, flax and ramie, dyestuffs and textile chemicals - also in textile machinery.

The textile industry is the mainstay of Pakistan's export trade and lies at the heart of its economy. It occupies an important position in generating profits in terms of foreign exchange earnings for the country. The cotton group accounted for more than $62 \%$ of the export earnings of Pakistan 2003-04. The textile and clothing manufactures together constitute approximately $70 \%$ of Pakistan's total exports.

WTO combined with technological developments as well as the changing market structure of the world textile industry is both a source of opportunity and threat for Pakistan.

The objective of this paper is to examine and analyse the institutional context with which the firms of the textile/apparel industry in Pakistan operate and assess the potential of this industry to grow to become a self-sustaining cluster of economic activity. The purpose is to construct a model which may be used to investigate the export performance and competitiveness of the textile/apparel industry in future. Some policy implications for the growth and sustained competitiveness of this industry in Pakistan are considered and discussed in this paper.

The plan of the paper is as follows: Section II gives brief review of literature on cluster approach to competitiveness. Section III presents analytical techniques and methodology. Results of the analysis are described in Section IV. It discusses the competitiveness of Pakistan's textile industry under the framework provided in Section III. Section V concludes the paper. It outlines several policy implications.

\section{REVIEW OF LITERATURE}

Industry clusters are geographical concentrations of competing, complementary, or interdependent firms and industries that do business with each other and/or have common needs for talent, technology, and infrastructure.

The concept of cluster-based industrial development is not a recent one. Industrial agglomerations and clusters have been the focus of scientific research as long as modern national economics have existed. Over a century ago, Alfred Marshall developed his idea of industrial districts. Other related concepts that have now become significant to the cluster approach are Ronald Coase's theories of the boundaries of the firms, first published in the 1930s (Coase, 1937), and Joseph Schumpeter's views of the dynamics of competition also presented at that time.

Michael Porter popularized the concept of industry clusters in his book 'Competitive Advantage of Nations' (1990). Based on his research in several countries, he developed 
the 'Diamond Framework', a model that offers insight into clusters and competitiveness. Porter contends that regions develop a competitive advantage based on their firms' ability to continually innovate, and that economic vitality is the direct product of the competitiveness of local industries.

Jacobs and De Man (1996) and Rosenfeld (1996, 1997) present an in-depth discussions of different definitions of industry clusters. Jacobs and De Man (1996, p. 425) argue that 'there is not one correct definition of the cluster concept..... different dimensions are of interest.' They include key dimensions like geographical or spatial clustering of economic activity, horizontal and vertical relationships between industry sectors, use of common technology, the presence of a central actor (i.e., a large firm, research center, etc.), and the quality of firm network, or firm cooperation (Jacobs and De Man 1996).

Rosenfeld (1997) emphasizes the role of social interaction and firm cooperation in determining the dynamic nature of a cluster. According to him an industry cluster is a geographically bounded concentration of similar, related or complementary businesses, with active channels for business transactions, communications and dialogue, that share specialized infrastructure, labor markets and services, and that are faced with common opportunities and threats.

Rosenfeld (1996), in particular, argues that information flow, is critical in an effective industry cluster, and, in order to facilitate information exchange, a social infrastructure is required. He emphasizes the importance of trust and a shared vision in order to create a dynamic nature of a cluster (Le Veen, 1998).

Porter (1998) has emphasized that underlying the phenomenon of clustering, is the exchange and flow of information about the needs, techniques and technology among buyers suppliers and related industries. Personal relationships, face to face communications and interaction among networks of individuals and institutions influence and accentuate the benefits associated with geographical concentration (Rosenfeld, 1997; Porter 1998).

This paper focuses on various formal and informal organizing mechanisms that play an essential role in the development and functioning of clusters. It limits itself to analysing the social environment under which the textile industry works in Pakistan. The emphasis is on capturing the mechanisms underlying the phenomenon of clustering.

\section{ANALYTICAL TECHNIQUES AND METHODOLOGY}

The competitiveness of the industry depends upon the ability of its firms to produce efficiently and to discover new and better ways to compete. This depends on the organizational and relationship building mechanisms that bind the cluster participants together in a relationship essential for value added transactions. The scope of research concerned with industrial linkages and intra cluster interchange varies from individual 
to individual. Intra cluster interchange refers to active channels for business transactions, communications and dialogue, sharing of specialized infrastructure, services and R\&D etc., within the establishments of the industry.

A large number of factors influence the social environment essential for cluster development that leads to innovation and sustained competitiveness. These factors have been divided into three groups and in each group the establishments were asked to rate the importance they give to the particular factor on a given scale. The three group of selected factors relate to;

a) Factors that influence the selection of suppliers

Six factors were selected and analysed i) Price ii) Quality iii) Delivery in time iv) Credibility of the owner v) Brand reputation vi) Distance between firm and supplier

b) Methods for attaining business information

Five factors were selected and analysed i) Direct observation ii) Informal contacts iii) Family or personal relationships iv) Joint venture or other collaborative agreements

c) Major sources of business information

Seven factors were selected and analysed i) Rivals ii) Customers iii) Suppliers iv) Equipment suppliers v) Banks and financial institutions vi) News/media vii) Collage/universities

\section{STATISTICAL TESTS}

The questions were designed to determine the 'degree' of importance given to various factors by the establishments. Pooled T-test has been used here.

a) Pooled t-test

Pooled t-test is the estimation procedure for the difference of two means when random samples of size $n_{1}$ and $n_{2}$ are taken from two independent normally distributed populations with means $\mu_{1}$ and $\mu_{2}$ respectively. If the standard deviations of the two populations are equal, the random variable

$$
\mathrm{t}=\frac{\left(\bar{X}_{1}-\bar{X}_{2}\right)-\left(\mu_{1}-\mu_{2}\right)}{s_{p} \sqrt{\left(1 / n_{1}\right)+\left(1 / n_{2}\right)}}
$$

has a t-distribution with $\mathrm{df}=n_{1}+n_{2}-2$

$$
s_{p}^{2}=\frac{\left(n_{1}-1\right) s_{1}^{2}+\left(n_{2}-1\right) s_{2}^{2}}{n_{1}+n_{2}-2}
$$


The null hypothesis states that the two population means are equal. For example in section 6.4.1 the hypothesis is

Ho : No significant difference was found in the importance given to 'Direct Observation' by the establishments producing finished goods and intermediate goods (i.e. $\mu_{1}=\mu_{2}$ thus $\mu_{1}-\mu_{2}=0$ ).

Ha : Significant difference was found in the importance given to 'Direct Observation' by the establishments producing finished goods and intermediate goods.

The equal-standard-deviations assumption is sometimes checked by performing a formal hypothesis test, called an F-test for the equality of two standard deviations.

F-test is extremely non-robust to deviations from normality: unless the populations are very close to normally distributed, the F-test may yield unreliable results (Weiss, p. 588). As the noted statistician George E.P. Box remarked: 'to make a preliminary test on variances (standard deviations) is rather like putting to sea in a rowing boat to find out whether conditions are sufficiently calm for an ocean liner to leave port' (as quoted in Weiss, 1995, p. 588).

In this study no F-test has been performed to test the equality of variances. Although in theory, the pooled t-test requires that the population standard deviations, $\sigma_{1}$ and $\sigma_{2}$ be equal. However according to Weiss (p. 603) if the population standard deviations are unequal but not too unequal and the sample sizes $n_{1}$ and $n_{2}$ are nearly the same then using the pooled t-test will not cause serious difficulties.

b) P-value

The P-value can be interpreted as the observed significance level of a hypothesis test. The P-value of a hypothesis test is equal to the smallest significance level at which the null hypothesis can be rejected, that is, the smallest significance level for which the observed sample data results in rejecting Ho (Weiss, 1995, p. 527). If the P-value is less than or equal to the specified significance level, then we reject the null hypothesis; otherwise we do not reject the null hypothesis.

\section{RESULTS}

A number of issues need to be kept in mind when interpreting the findings of this study. First the data was collected from a limited geographical base. Secondly the investigation of the dynamic aspects of industrial linkages was limited because most of the historical data on industrial linkage was based upon personal recollection rather than records.

Examination of the structure of the network under which the textile/apparel industry operates reveals that the social relationships associated with geographical clustering of firms have not developed in this industry. Although geographical clustering has 
created potential for economic value, the industry has so far failed to ensure the full realisation of this potential. For example proximity of suppliers and strong backward linkages have not been able to facilitate valuable information flow within the cluster.

\section{Factors influencing the selection of Suppliers (Statistical Appendix A)}

Five factors were analyzed for their influence on the selection of suppliers. These factors were i) Price of the products ii) Quality of the products iii) Delivery in time iv) Credibility of the owner v) Distance between the firm and supplier. The establishments were asked to rate the importance rate the importance they give to these factors on the scale of 1 to 5 ( 1 being not important at all and 5 being critically important).

Pooled t-test was used to determine whether the establishments producing finished goods and intermediate goods differ in the importance they give to the selected factors. The survey findings indicate that the selection of suppliers was primarily based upon the competitive nature of the products by the interviewed establishments. The quality and price of the products were considered to be critically important factor by a majority of the interviewed establishments for selecting the suppliers. This was particularly true in the case of establishments producing commodity products of intermediate nature. Among various factors, distance was ranked as one of the least important factors in finding suppliers. T-tests indicate that the establishments producing intermediate goods were more competitive in nature as far as price and quality were concerned.

\section{Methods of Attaining Business Information (Statistical Appendix B)}

Information plays a paramount role in the interchange within clusters. Five factors were selected to analyze how the informational interchange within the establishments in this industry takes place. These factors were i) Direct observation ii) Informal contacts iii) Family or personal relationships iv) Joint ventures or collaborative agreements v) Conferences and seminars. The establishments were asked to rate the importance they give to these factors on the scale of 1 to 5 . The null hypothesis states that the relative importance given to a factor does not differ with the nature of the establishments. Direct observation was the single most prominent method of attaining business information.

Family/personal relationships play an essential role in the functioning of cluster linkages. The survey findings indicate that these relationships were still underdeveloped in this industry cluster although the establishments producing finished goods considered it significantly more important than the establishments producing intermediate goods. Neutral facilitators like conferences and collaborative agreements etc. can be an efficient source of communication where family or trust relationships are lacking. Nonetheless the survey indicates that a high proportion of interviewed establishments did not consider collaborative agreements or joint ventures an important method of business information. Conferences were considerably considered more important than collaborative agreements. 
Seven factors were analysed to understand the social environment under which the informational interchange takes place in the industry. These factors were i) Rivals ii) Customers iii) Suppliers iv) Equipment suppliers v) Banks and financial institutions vi) News/media vii) Colleges/universities. The establishments were asked to rate the importance they give to these factors on the scale of 1 to 5. T-test statistic was used here to analyse whether the importance given to these factors differed with the nature of the establishments.

The survey results indicate that the customers were the most important source of information for the surveyed establishments. This is in line with the fact that the surveyed establishments were mainly export oriented firms that relied primarily on foreign machinery, technology and marketing services. Rivals were significantly a more important source of information for the establishments producing finished goods. This is because these firms were producing a range of products for foreign markets whereas the establishments producing intermediate products had confined themselves to few low priced products that had the potential of being consumed both in the local and foreign markets. In short the survey results indicate that customers/equipment suppliers provided an important mechanism for informational interchange in the industry.

The process of cluster development depends heavily on how the local educational institutions respond to the cluster needs. The research indicates that collages and universities were not an important source of information for the establishments. This is not only because of the low percentage of students enrolled in professional collages and universities but also the fact that these institutions mostly have a theoretical approach which is not in line with the needs of the industry. This strongly relates to the low R\&D activities of the firms themselves. However the survey findings indicate that banks and financial institutions provided an important platform of informational interchange to the surveyed establishments.

\section{CONCLUSION}

Although the research was limited in both geographical and sectoral scope, its findings may have considerable planning implications for the government and companies. Pakistan is stuck in low skill and low technical competence trap. The East Asian economies were able to achieve a successful transition to higher value added production by focusing on the vocational and technical skills required to meet the needs of the industry. Primary and secondary education in Pakistan should be accompanied by an expansion of vocational training to provide skilled labour for its export oriented industries. This can be an appropriate alternative to the bulk of Pakistanis who are unable to acquire academic qualifications for their working careers. The status and resources of polytechnics should also be improved so that they provide a true alternative to universities for both students and educators. Curricula should be developed with input from appropriate industry associations to ensure that relevant skills are developed. 
Korea managed to improve the quality of its workforce through the establishment of Economic Planning Board (EPB). The main task of this EPB has been to work closely with ministries of education, labour and science and technology and to coordinate the education and training requirements of the economic development strategy. In Pakistan there are no close links between schools/universities and industry. There is an urgent need for a similar type of linking mechanism that could encourage schools, universities and industries to work closely together.

\section{STATISTICAL APPENDIX A}

Price of the Products:

(Percentages)

\begin{tabular}{|l|c|c|c|c|c|}
\hline Scale & $\mathbf{1}$ & $\mathbf{2}$ & $\mathbf{3}$ & $\mathbf{4}$ & $\mathbf{5}$ \\
\hline Finished Goods & 5.88 & 0 & 5.88 & 35.29 & 52.94 \\
\hline Intermediate Goods & 0 & 0 & 5.56 & 16.67 & 77.78 \\
\hline
\end{tabular}

Scale: $1=$ Not important at all $5=$ Critically important

Quality of the Products (inputs):

(Percentages)

\begin{tabular}{|l|c|c|c|c|c|}
\hline Scale & $\mathbf{1}$ & $\mathbf{2}$ & $\mathbf{3}$ & $\mathbf{4}$ & $\mathbf{5}$ \\
\hline Finished Goods & 5.88 & 0 & 5.88 & 35.29 & 52.94 \\
\hline Intermediate Goods & 0 & 0 & 5.56 & 16.67 & 77.78 \\
\hline \\
Scale: 1= Not important at all \\
5= Critically important & & $\begin{array}{l}\text { t-value } \mathbf{:}-\mathbf{- 4 . 3 5 3} \\
\text { df } \\
\text { p-value }: \mathbf{0 . 0 0 0}\end{array}$ \\
\hline
\end{tabular}

Delivery in Time:

(Percentages)

\begin{tabular}{|l|c|c|c|c|c|}
\hline Scale & $\mathbf{1}$ & $\mathbf{2}$ & $\mathbf{3}$ & $\mathbf{4}$ & $\mathbf{5}$ \\
\hline Finished Goods & 11.76 & 5.88 & 41.18 & 17.65 & 23.53 \\
\hline Intermediate Goods & 0 & 0 & 0 & 27.78 & 72.22 \\
\hline
\end{tabular}


Credibility of the Owner:

(Percentages)

\begin{tabular}{|l|c|c|c|c|c|}
\hline Scale & $\mathbf{1}$ & $\mathbf{2}$ & $\mathbf{3}$ & $\mathbf{4}$ & $\mathbf{5}$ \\
\hline Finished Goods & 6.25 & 18.75 & 18.75 & 12.50 & 43.75 \\
\hline Intermediate Goods & 5.56 & 5.56 & 22.22 & 11.11 & 55.56 \\
\hline
\end{tabular}

Scale: $1=$ Not important at all $5=$ Critically important

Brand Reputation:

(Percentages)

\begin{tabular}{|l|c|c|c|c|c|}
\hline Scale & $\mathbf{1}$ & $\mathbf{2}$ & $\mathbf{3}$ & $\mathbf{4}$ & $\mathbf{5}$ \\
\hline Finished Goods & 5.88 & 29.41 & 17.65 & 11.76 & 35.29 \\
\hline Intermediate Goods & 0 & 16.67 & 16.67 & 33.33 & 33.33 \\
\hline
\end{tabular}

Scale: $1=$ Not important at all $5=$ Critically important

Distance between Firm and Supplier:

(Percentages)

\begin{tabular}{|c|c|c|c|c|c|}
\hline Scale & 1 & 2 & 3 & 4 & 5 \\
\hline Finished Goods & 23.53 & 41.18 & 17.65 & 17.65 & 0 \\
\hline Intermediate Goods & 77.78 & 11.11 & 11.11 & 27.78 & 0 \\
\hline \multicolumn{4}{|c|}{ Scale: $\begin{aligned} 1 & =\text { Not important at all } \\
4 & =\text { Critically important }\end{aligned}$} & $\begin{array}{l}\text { t-valu } \\
\text { df } \\
\text { p-val }\end{array}$ & $\begin{array}{l}: \mathbf{3 . 0 7 6} \\
: \mathbf{3 3} \\
: \mathbf{0 . 0 0 4}\end{array}$ \\
\hline
\end{tabular}

\section{STATISTICAL APPENDIX B}

Direct Observation:

\begin{tabular}{|l|c|c|c|c|c|}
\hline Scale & $\mathbf{1}$ & $\mathbf{2}$ & $\mathbf{3}$ & $\mathbf{4}$ & $\mathbf{5}$ \\
\hline Finished Goods & 10.53 & 0 & 5.26 & 10.53 & 73.68 \\
\hline Intermediate Goods & 0 & 0 & 5.56 & 11.11 & 83.33 \\
\hline
\end{tabular}

Scale: $1=$ Not important at all $5=$ Critically important 
Informal Contacts:

(Percentages)

\begin{tabular}{|l|c|c|c|c|c|}
\hline Scale & $\mathbf{1}$ & $\mathbf{2}$ & $\mathbf{3}$ & $\mathbf{4}$ & $\mathbf{5}$ \\
\hline Finished Goods & 5.26 & 21.05 & 26.32 & 31.58 & 15.79 \\
\hline Intermediate Goods & 33.33 & 27.78 & 5.56 & 27.78 & 5.56 \\
\hline \\
Scale: 1= Not important at all \\
5= Critically important & & $\begin{array}{l}\text { t-value } \mathbf{:} 2.084 \\
\text { df } \\
\text { p-value } \mathbf{0} \mathbf{0 . 0 4 5}\end{array}$ \\
\hline
\end{tabular}

Family or Personal Relationships:

(Percentages)

\begin{tabular}{|l|c|c|c|c|c|}
\hline Scale & $\mathbf{1}$ & $\mathbf{2}$ & $\mathbf{3}$ & $\mathbf{4}$ & $\mathbf{5}$ \\
\hline Finished Goods & 0 & 15.79 & 36.84 & 21.05 & 26.32 \\
\hline Intermediate Goods & 33.33 & 22.22 & 16.67 & 5.56 & 22.22 \\
\hline
\end{tabular}

Joint Venture or other Collaborative Agreements:

(Percentages)

\begin{tabular}{|c|c|c|c|c|c|}
\hline Scale & 1 & 2 & 3 & 4 & 5 \\
\hline Finished Goods & 0 & 21.05 & 31.58 & 31.58 & 15.79 \\
\hline Intermediate Goods & 50 & 16.67 & 16.67 & 5.56 & 11.11 \\
\hline \multicolumn{4}{|c|}{ Scale: $\begin{aligned} 1 & =\text { Not important at all } \\
5 & =\text { Critically important }\end{aligned}$} & $\begin{array}{l}\text { t-valt } \\
\text { df } \\
\text { p-val }\end{array}$ & $\begin{array}{l}: 3.255 \\
: 35 \\
: 0.003\end{array}$ \\
\hline
\end{tabular}

Conferences and Seminars:

(Percentages)

\begin{tabular}{|l|c|c|c|c|c|}
\hline Scale & $\mathbf{1}$ & $\mathbf{2}$ & $\mathbf{3}$ & $\mathbf{4}$ & $\mathbf{5}$ \\
\hline Finished Goods & 10.53 & 15.79 & 15.79 & 15.79 & 42.11 \\
\hline Intermediate Goods & 22.22 & 22.22 & 33.33 & 5.56 & 16.67 \\
\hline \\
Scale: 1= Not important at all \\
5= Critically important & & $\begin{array}{l}\text { t-value } \mathbf{: 1 . 9 5 4} \\
\text { df } \\
\text { p-value : } \mathbf{0 . 0 5 9}\end{array}$ \\
\hline
\end{tabular}




\section{STATISTICAL APPENDIX C}

Rivals:

(Percentages)

\begin{tabular}{|c|c|c|c|c|c|}
\hline Scale & 1 & 2 & 3 & 4 & 5 \\
\hline Finished Goods & 0 & 10.53 & 0 & 5.26 & 84.21 \\
\hline Intermediate Goods & 33.33 & 11.11 & 27.78 & 0 & 27.78 \\
\hline \multicolumn{4}{|c|}{ Scale: $\begin{aligned} 1 & =\text { Not important at all } \\
5 & =\text { Critically important }\end{aligned}$} & $\begin{array}{l}\text { t-valt } \\
\text { df } \\
\text { p-val }\end{array}$ & $\begin{array}{l}4.251 \\
35 \\
0.000\end{array}$ \\
\hline
\end{tabular}

Customers:

(Percentages)

\begin{tabular}{|l|c|c|c|c|c|}
\hline Scale & $\mathbf{1}$ & $\mathbf{2}$ & $\mathbf{3}$ & $\mathbf{4}$ & $\mathbf{5}$ \\
\hline Finished Goods & 0 & 10.53 & 15.79 & 15.79 & 57.89 \\
\hline Intermediate Goods & 0 & 0 & 11.11 & 0 & 88.89 \\
\hline
\end{tabular}

Scale: $1=$ Not important at all $5=$ Critically important

Suppliers:

(Percentages)

\begin{tabular}{|l|c|c|c|c|c|}
\hline Scale & $\mathbf{1}$ & $\mathbf{2}$ & $\mathbf{3}$ & $\mathbf{4}$ & $\mathbf{5}$ \\
\hline Finished Goods & 0 & 5.26 & 26.32 & 42.11 & 26.32 \\
\hline Intermediate Goods & 5.56 & 0 & 16.67 & 33.33 & 44.44 \\
\hline
\end{tabular}

Scale: $1=$ Not important at all $5=$ Critically important

Equipment Suppliers:

(Percentages)

\begin{tabular}{|c|c|c|c|c|c|}
\hline Scale & 1 & 2 & 3 & 4 & 5 \\
\hline Finished Goods & 0 & 0 & 31.58 & 47.37 & 21.05 \\
\hline Intermediate Goods & 0 & 0 & 11.11 & 11.11 & 77.78 \\
\hline \multicolumn{4}{|c|}{ Scale: $\begin{aligned} 1 & =\text { Not important at all } \\
5 & =\text { Critically important }\end{aligned}$} & $\begin{array}{l}\text { t-valu } \\
\text { df } \\
\text { p-valı }\end{array}$ & $\begin{array}{l}:-3.292 \\
: 35 \\
: 0.002\end{array}$ \\
\hline
\end{tabular}


Banks and Financial Institutions:

(Percentages)

\begin{tabular}{|l|c|c|c|c|c|}
\hline Scale & $\mathbf{1}$ & $\mathbf{2}$ & $\mathbf{3}$ & $\mathbf{4}$ & $\mathbf{5}$ \\
\hline Finished Goods & 0 & 10.53 & 5.26 & 42.11 & 42.11 \\
\hline Intermediate Goods & 0 & 11.11 & 5.56 & 5.56 & 77.78 \\
\hline
\end{tabular}

Scale: $1=$ Not important at all $5=$ Critically important

News / Media:

(Percentages)

\begin{tabular}{|l|c|c|c|c|c|}
\hline Scale & $\mathbf{1}$ & $\mathbf{2}$ & $\mathbf{3}$ & $\mathbf{4}$ & $\mathbf{5}$ \\
\hline Finished Goods & 11.11 & 0 & 11.11 & 55.56 & 22.22 \\
\hline Intermediate Goods & 0 & 5.56 & 33.33 & 5.56 & 55.56 \\
\hline
\end{tabular}

Scale: $1=$ Not important at all $5=$ Critically important

Colleges / Universities:

(Percentages)

\begin{tabular}{|l|c|c|c|c|c|}
\hline Scale & $\mathbf{1}$ & $\mathbf{2}$ & $\mathbf{3}$ & $\mathbf{4}$ & $\mathbf{5}$ \\
\hline Finished Goods & 21.05 & 21.05 & 26.32 & 10.53 & 21.05 \\
\hline Intermediate Goods & 23.53 & 11.76 & 29.41 & 17.65 & 17.65 \\
\hline
\end{tabular}

Scale: $1=$ Not important at all $5=$ Critically important

\section{REFERENCES}

Aftab, K. \& E. Rahim, (1986). "Emergence of Small-Scale Engineering Sector", Journal of Development Studies, 23:1, pp. 61-66.

Ahmed, V. \& R. Amjad, (1984). The Management of Pakistan's Economy, 1947-82, Karachi, Oxford University Press.

Akbar, N. (1992). "Liberalisation of Foreign Trade and International Competitiveness", in A. Nasim, Financing Pakistan's Development in the 1990s, pp. 135-172, Oxford University Press. 
Aslam, M. (1997). Perspective on Development Planning in Pakistan, Oxford University Press.

Balassa, B. (1985). "Policy Choices for Developing Countries", Indian Economic Review, 23:1, pp. 27-44.

Boekholt, P. \& B. Thuriaux (1999). "Public Policies to Facilitate Clusters; Background, Rationale and Policy Practices in International Perspective", In: Boosting Innovation: The Cluster Approach, OECD Proceedings, ISBN 92-64-17080-4.

Buckley, P.J. \& J. Michie, eds. (1996). "Firms, Organisations and Contracts: A Reader in Industrial Organization”, Oxford, Oxford University Press.

Caves R.E. (1988). “The Empirical Determinants of Vertical Integration”, Journal of Economic Behaviour and Organization, 9, pp. 265-279.

Chandler, A.D. Jr. (1990). "Scale and Scope: The Dynamics of Industrial Capitalism", Cambridge, Massachusetts: Belknap Press.

Cheema, A. (1995). "Pakistan's Textile Policy and Trade Performance, 1972-90", Sidney Sussex College, Cambridge (mimeo).

Colgan, C.S. \& C. Baker (2000). "Prospects for Marine Biotechnology in Maine", Edmunds Muskie School of Public Service, University of Southern Maine, retrieved on July 2002, from World Wide Web:

http://www.muskie.usm.maine.edu/csc/homepage/Maine\%20Biotech\%20Report.pdf

Coombs, R., P. Saviotti \& V. Walsh (1987). "Economics and Technological Change", London, Macmillan.

Crocombe, G.T., M.J. Enright \& M.E. Porter, (1991). “Upgrading New Zealand's Competitive Advantage", Oxford University Press, New York.

Doeringer, P.B. \& D.G. Terkla, (1995). "Business Strategy and Cross-industry Clusters", Economic Development Quarterly, 9, pp. 225-37.

Dow, G.K. (1987). "The Function of Authority in Transaction Cost Economics", Journal of Economic Behaviour and Organization, 8, pp. 13-38.

Dudaro, S. (1993). "Exports of Economic Growth: A Reconsideration", Journal of Developing Areas, 27, pp. 227-244.

Enright, M., J.A. Frances \& E.S. Saavedra (1996). "Venezuela: The Challenge of Competitiveness", Basingstoke: Macmillan. 
The Export Promotion Bureau, (1995). "Uruguay Round of Trade Talks: Impact on Pakistan’s Exports”, Export Promotion Bureau, Karachi.

Fairbank, M. \& S. Lindsay, (1997). "Plowing the Sea: Nurturing the Hidden Sources of Growth in the Development World", Harvard Business School Press.

Francis, W.P. (1983). "Industrial Linkage, Locational Advantage and Adaptive Behaviour, in Manufacturing", Ph.D. Thesis, University of Sheffield.

Freeman, C. (1982). "The Economics of Industrial Innovation”, London, Frances Pinter.

Gherzi Textile Report (1992). "Development of the Market Based Strategy for the Pakistan Textile and Clothing Industry", Export Promotion Bureau, Pakistan.

Goodman, E. \& J. Bamford, eds (1989). "Small Firms and Industrial Districts in Italy", London: Routledge.

Government of Pakistan (1995). Pakistan Statistical Yearbook 1995, Federal Bureau of Statistics, Statistics Division, Islamabad.

Government of Pakistan (1998a). "Trade Liberalisation and Export Promotion; Pakistan 2010: Long Term Perspective Study”, Islamabad, Pakistan.

Government of Pakistan (1998b). "Building Pakistan's Technological Competence, Pakistan 2010: Long Term Perspective Study”, Islamabad, Pakistan.

Government of Pakistan (1998c). "Creating Change through private Sector-led Industrialisation: Pakistan 2010: Long Term Perspective Study”, Islamabad, Pakistan.

Government of Pakistan. Economic Survey, Various Issues, Finance Division, Islamabad.

Government of Pakistan. Census of Manufacturing Industry, Various Issues, Karachi, Pakistan.

Government of Pakistan and Japan International Co-operation Agency (JICA) (1991). "Study on the Textile Industry Development Program in Islamic Republic of Pakistan." Islamabad, Pakistan.

Government of Pakistan. “50 Years of Pakistan in Statistics,” Volume IV (1982-1997). Federal Bureau of Statistics, Statistics Division.

Government of Pakistan (1992). "Pakistan Leather Industry Development Report", Islamabad, Pakistan. 
Government of Pakistan (2000). “Textile Vision 2005”, Summary Report, pp. 10-47, Islamabad, Pakistan.

Government of Pakistan (1992-93). “Pakistan's Surgical Instruments: Buyers Guide”, International Business Publications.

Gujrati, D. N. (1995). “Basic Econometric,” 3rd Edition, London, McGraw-Hill.

Haq, M. and K. Haq (1998). “Human Development in South Asia 1998,” Oxford University Press.

The H. Humphery Institute of Public Affairs (1999). “An Economic Development Report for Minnesota”, Minneapolis, Minnesota. Retrieved on July 2002 from World Wide Web: http://www.hhh.umn.edu/centers/slp/edweb/ic-rep.htm

Hijazi, T. (1995). "Role of Institutions in Industrial Development of Pakistan", The Pakistan Development Review, 34:4, pp. 1081-1090.

Jacobs, D. and De Man (1996). "Clusters, Industrial Policy and Firm Strategy: A Menu Approach”, Technology Analysis and Strategic Management, pp. 425-437.

Katz, J. (1984). "Dynamic Technological Innovation and Dynamic Comparative Advantage: Further Reflections on a Comparative Case Study Program", Journal of Development Economics, 16, pp. 13-38.

Krugman, P. (1991). “Geography and Trade”, Leuven: Leuven University Press.

Lall, S. (1990). “Building Industrial Competitiveness in Developing Countries”, OECD, Paris.

Lall, S., (1998). "Meeting the Human Capital Needs of Maturing Asian Economies", in C. Foy, F. Harrigan and D.O' Connor, The Future of Asia in World Economy, pp. 149-193.

Lall, S. (1984). "Exports of Technology by Newly Industrializing Countries", Special Issue, World Development, 12:5

Lewis, S. (1970). "Economic Policy and Industrial Growth in Pakistan”, George Allen and Unwin, London.

Lewis, S. (1970). "Pakistan: Industrialization and Trade Policies", George Allen and Unwin, London.

Lever, W.F. (1974). "Manufacturing Linkages and the Search for Suppliers and Markets", in F.E. I. Hamilton, ed., Spatial Perspective on Industrial Organisation and Decision Making, pp. 309-333, London, New York, Wiley. 
Le Veen, J. (1998). Industry Cluster Literature Review, Urban and Regional Development. Retrieved on July 2002 from World Wide Web: http://www.unc.edu/depts/dcrpweb/courses/261/litrev.htm

Little, I., T. Scitovsky \& M. Scott, (1970). "Industry and Trade in Some Developing Countries", London, Oxford University Press.

Makhdoomi, S. (2000). "Price Competitiveness and Performance of Manufactured Exports: A Case Study of Pakistan 1970-98”, Ph.D. Thesis, University of Strathclyde.

Malik, K. (1996). “The Competitive Advantage of Pakistan”, M.Sc. Dissertation, University of Strathclyde.

Malik, S.J. (1994). "Pakistan's Economic Performance 1947-1993: A Descriptive Analysis", Lahore-Pakistan, Sure Publishers.

Marshall, J.N. (1987). "Industrial Change, Linkages and Regional Development", in F.W. Lever, ed., Industrial Changes in United Kingdom, pp. 108-22, Croom Helm.

Marshall J.N. (1979). “Ownership, Organization and Industrial Linkage: A Case Study in Northern Region of England”, Regional Studies, 13, pp. 531-537.

McCormick, D. (1999). “African Enterprise Clusters and Industrialization: Theory and Reality", World Development, 27:9, 1531-1551.

Mead, D.C. \& C. Liedholm (1998). "The Dynamics of Micro and Small Enterprises in Developing Countries", World Development, 26:1, pp. 61-74.

Mehmet, O. (1978). "Economic Planning and Social Justice in Developing Countries", London, Croom Helm.

Moss, S. (1981), “An Economic Theory of Business Strategy”, Oxford: Martin Robertson.

Moser A.C. \& G. Kalton, (1985). "Survey Methods in Social Investigation, 2nd Edition," Gower Publishing Company Ltd.

Naqvi, S.N.H. \& K.A. Saeed, (1993). "External Shocks and Domestic Adjustment: Pakistan's case 1970-1990”, p. 46, University Grant Commission, Islamabad, mimeo.

Papanek, G.F. (1967). "Pakistan's Development, Social Goals and Private Incentives", Harvard University Press, Cambridge, Mass.

Peteraf, M.A. (1993). "The Cornerstones of Competitive Advantage: A Resourcebased View”, Strategic Management Journal, 14, pp. 179-19. 
Penttinen, R. (1994). "Summary of the Critique on Porter's Diamond Model”, discussion paper 462, The Research Institute of the Finnish Economy (ETLA), Helsiniki.

Piore, M. \& C. Sabel, (1984). "The Second Industrial Divide: Possibilities for Prosperity", New York: Basic Books.

Porter, M.E. (1998). “The Competitive Advantage of Nations”, London, Macmillan Press Ltd.

Porter, M.E. \& V.E. Millar (1985). "How Information Gives You Competitive Advantage", Harvard Business Review, 4, pp. 149-160.

Porter M.E. (1996). “On Competition”, Boston, Harvard Business School Publishing.

Porter, M.E. (2001). “The Competitive Advantage of Singapore,” retrieved June 2002 from World Wide Web:

http://www.people.hbs.edu/mporter/caon\%20singapore\%2008-02-01\%ck.pdf

Ramanathan, K. (1994). “Technology-based Development of a Productive Enterprise: A case Study", Paper prepared for Seminar on "New International Environment and Industrialisation Policy in Asia", Institute of Social Studies, The Hague, The Netherlands and the Asian Institute of Technology, Bangkok, Thailand, September 17-30, Bangkok Thailand.

Rauf, S. (1994). "Structure of Large-Scale Manufacturing Industries of Pakistan: 19501988”, Pakistan Development Review, 17:2, pp. 1373-1384.

Rosenfeld, S.A. (1997). "Bringing Business Clusters into the Mainstream of Economic Development”, European Planning Studies, 5:1, 3-23.

Saeed, K.A. (2000). “Economy of Pakistan”, Lahore, Newfine Printing Press.

Scherer, F.M. (1980). "Industrial Market Structure and Economic Performance", 2nd Edition, Chicago, Ill Rand McNally.

Schmitz, H. (1995). "Collective Efficiency: Growth Path for Small-Scale Industry", Journal of Development Studies, 31:4, pp. 529-566.

Schmitz, H. \& K. Nadvi (1999). "Clustering and Industrialization: Introduction", World Development, 27:9, pp. 1503-1514.

Scott, A.J. (1983) "Industrial Organization and Logic of Intra-metropolitan: Theoretical Considerations”, Economic Geography, 59, pp. 233-255.

Schumpeter, J.A. (1934). The Theory of Economic Development, Cambridge, Mass: Harvard University Press. 
Sternberg, E. (1991). "The Sectoral Cluster in Economic Development Policy: Lessons from Rochester and Buffalo”, Economic Development Quarterly, 5, pp. 342-356.

Stout, D.K. et al. (1977). "International Price Competitiveness, Non-price Factors and Export Performance”, London, National Economic Development Office.

Taylor, M.J. (1978). "Linkage Change and Organizational Growth: The Case of the West Midlands Ironfoundary Industry", Economic Geography, 54:4, pp. 315-36.

Thomas, R.L. (1993). "Introductory Econometrics: Theory and Applications," 2nd Edition, London, Longman.

Tambunan, T. (1994). "Long-term Development of Small-Scale Industries in Relation to Economic Development: Looking for General Propositions", The Pakistan Development Review, 33:2, pp. 165-190.

Taylor, M.J. (1973). "Local Linkage, External Economies and the Infoundary of the West Midlands and East Lancashire”, Regional Studies, 7, pp. 387-400.

Taylor, M.J. (1975). “Organizational Growth, Spatial Interaction and Location Decision Making”, Regional Studies, 9, pp. 313-323.

Teece, D.J. (1981). "The Market for Know-how and Efficient International Transfer Technology", Annals of the American Academy of Political and Social Science.

UNIDO (1990). "Pakistan: Towards Industrial Liberalization and Revitalization", Basil Blackwell, Oxford, pp. 19-22.

Viitamo, E. (2001). "Cluster Analysis and the Forest Sector", retrieved June 2002, from the World Wide Web:

http://www.iiasa.ac.at/Publications/Documents/1R-01-016.pfd

Williamson, O.E. (1975). "Markets and Hierarchies: Analysis and Antitrust Implications", New York: Free Press.

World Bank (1997). "World Development Report”, New York: Oxford University Press.

Wayne, E.N. (1987). “The Economics of Developing Countries”, Prentice-Hall International Editions.

World Bank (1990). "Textiles Trade and the Developing Countries: Eliminating the Multi Fiber Arrangement in the 1990s", World Development Report, Oxford University Press, New York. 
World Bank. "Managing Restructuring in the Textile and Garment Subsector: Examples from Asia”, in S. D. Meyanathan, ed., EDI Seminar Series, Washington DC.

Walpole, R.E. (1982). “Introduction to Statistics”, New York, Macmillan.

Weiss, N.A. \& M.J. Hassett (1995). "Introductory Statistics", 4th Edition, AddisonWesley Publishing Company.

Williamson, O.E. (1981). "The Economics of Organisation: The Transaction Costs Approach”, American Journal of Sociology, 87, pp. 548-77.

Yong-Woong Kim (1991). "Organization and Industrial Linkage in Developing Countries: A Case Study of Less Industrialized Region in Korea”, Ph.D. Thesis, University of Sheffield.

Zaidi, S.A. (1999). "Issues in Pakistan’s Economy”, Oxford University Press.

\section{THE MARKET ETHICS}

"The principle was sanctioned in the world of commerce by Adam Smith in his Wealth of Nations. Implicit in Smith's description of market economy is the idea that selfish actions in the marketplace are virtuous because they contribute to efficient operation of the economy. This efficient operation is in turn responsible for the higher goods of prosperity and optimum use of resources. Decision makers may take selfish actions and be motivated by personal gain in their business dealings. They should ask whether their actions in the market further financial self-interest. If so, the actions are ethical.

This form of ethical guidance is applicable only in market situations. It is not useful in interpersonal relations and therefore is not a universal principle. Also, there are areas of market behavior where society has determined that the broad public interest is not furthered by selfish market behavior. Antitrust statutes are prime examples of legislated ethics here."

Steiner and Steiner. Business, Government and Society: A Managerial Perspective, p. 221. 